\title{
Short communication: Variation in the composition and properties of Swedish raw milk for ultra-high-temperature processing
}

\author{
Maria A. Karlsson,,${ }^{* 1}$ Maud Langton, ${ }^{*}$ Fredrik Innings, † Malin Wikström,‡ and Åse Sternesjö Lundh* \\ *Department of Molecular Sciences, BioCenter, Swedish University of Agricultural Sciences, PO 7015, 75007 Uppsala, Sweden \\ †Tetra Pak Processing Systems AB, Bryggaregatan 23, 22736 Lund, Sweden \\ ¥Norrmejerier Ek. Förening, Mariehemsvägen 210, 90650 Umeå, Sweden
}

\begin{abstract}
The composition and properties of raw milk are of great importance for the quality and shelf life of the final dairy product, especially in products with a long shelf life [e.g., ultra-high-temperature (UHT)-treated milk]. The objective of this study was to investigate the compositional variation in raw milk samples before processing at the dairy plant. Moreover, we wanted to investigate the effect of the UHT process on this variation (i.e., if the same variation could be observed in the corresponding UHT milk). The quality traits analyzed included detailed milk composition, counts of total and psychrotrophic bacteria, proteolytic activity, and color, as well as predictive measures of stability (i.e., ethanol stability and heat coagulating time). Samples of raw milk and the corresponding produced UHT milk were collected and analyzed on a monthly basis during 1 yr. Principal component analysis was used to identify months showing similarities and differences with respect to total variation. In contrast to previous studies, we observed only small variations between months and no clear effect of season for the raw milk. For the UHT milk, July and the winter months (December, January, and February) tended to separate from the other months. Quality traits showing significant variation were only to some extent identical in raw milk and UHT-processed milk. A better understanding of the natural variation in raw milk quality will provide opportunities to improve the shelf life of UHT-treated milk products.
\end{abstract}

Key words: raw milk quality, ultra-high-temperature milk, seasonal variation, principal component analysis

\section{Short Communication}

The composition and properties of the raw milk are of great importance for all dairy products, affecting the

Received October 20, 2016.

Accepted December 21, 2016.

${ }^{1}$ Corresponding author: maria.a.karlsson@slu.se quality and shelf life. In general, raw milk quality traits vary with breed, feed, stage of lactation, and animal health, as well as season (Fox and McSweeney, 1998). In Sweden, calving patterns are nonseasonal, resulting in bulk milk from cows at various stages of lactation all year round (Jordbruksverket, 2012). This will reduce seasonal variation in raw milk composition, although not entirely eliminate it (Auldist et al., 1998). Apart from the lactation stage, feed is the main factor contributing to variation in the raw milk. Swedish legislation specifies that cows should be outdoor grazing for a minimum of 2 mo during summer, and the majority of the cows are fed silage during the indoor period. Milk quality traits reported to vary with season include protein and fat (Lindmark-Månsson et al., 2003; Heck et al., 2009), mineral content (Sola-Larrañaga and Navarro-Blasco 2009), but also several other traits (Gaucher et al., 2008).

Variation in milk composition has a multifactorial background and constitutes a challenge for dairy industry, especially in products with long shelf life (e.g., UHT-treated milk). Globally, UHT milk is an important dairy product, although in the northern hemisphere, UHT processing is less common. With the increasing production of novel UHT milk-based beverages, variation in product stability has led to a growing interest in the effect of raw milk composition on stability during storage. Quality traits considered to have most influence on the stability of UHT milk include $\mathrm{pH}$, calcium, protein composition, urea, and bacterial count, and consequently also the underlying factors giving rise to variation in these quality traits (Williams, 2002).

The composition of milk delivered to Swedish dairies was previously investigated in 1996 (LindmarkMånsson et al., 2003) and 2009 (Lindmark-Månsson, 2012). The objective of our work was to investigate the monthly variation in raw milk during $1 \mathrm{yr}$, including quality traits (e.g., composition, bacterial count, SCC, enzymatic activity, color, ethanol stability, and heat coagulation time). Moreover, we wanted to study if the variation in some of the quality traits was affected by the UHT process. Our hypothesis was that differences 
between raw milk produced during grazing and indoor periods exist and that these differences will persist in the UHT-processed milk.

In total, 22 samples (i.e., 11 raw dairy silo milk samples and 11 samples corresponding to the UHT milk produced from the sampled raw milk) were used in the study. A representative sample of the raw milk was collected on a monthly basis during 1 yr with the exception of August at the Norrmejerier dairy plant in Lulea, northern Sweden. The raw milk, consisting of pooled milk provided from approximately 80 farms located in the surrounding region around the dairy plant, was sampled and transported refrigerated to the Swedish University of Agricultural Sciences (SLU), Uppsala. As part of the process, the raw milk was standardized to $1.5 \%$ fat and the UHT treatment was performed using indirect tubular heat exchangers at $137^{\circ} \mathrm{C}$ for 4 s. Samples of the UHT milk were transported to SLU at ambient temperature. Analysis of the raw milk and UHT milk was initiated the day after delivery to SLU, resulting in raw milk samples not older than $4 \mathrm{~d}$, including cold storage on farms and at the dairy plant, and UHT milk samples with an age of 5 to $14 \mathrm{~d}$. Samples were also aliquoted and frozen at $-20^{\circ} \mathrm{C}$ for later thawing and analysis of mineral content, citric acid, urea, and enzymatic activity. All measurements were done at ambient temperature unless otherwise stated.

The content of TS, protein, fat, and lactose in milk was measured by near-infrared spectroscopy, using MilkoScan FT120 (Foss, Hillerød, Denmark). The protein profile was analyzed by capillary electrophoresis, as previously described by Gustavsson et al. (2014). Citrate content was analyzed by HPLC according to the method described by Andersson and Hedlund (1983). Urea was determined using the AutoAnalyzer III procedure (SEAL Analytical GmbH, Norderstedt, Germany) according to Eriksson and Rustas (2014). Calcium, potassium, sodium, and magnesium were analyzed as described in ISO 8070 (ISO/IDF, 2007) using atomic absorption spectrometry (AAnalyst 100, Perkin Elmer, Waltham, MA).

Counts of total bacteria and psychrotrophic microorganisms were enumerated in raw milk samples with colony count techniques according to the NMKL method 86 (NMKL, 1999) and ISO 8552 (ISO/IDF, 2004), respectively.

The CIELAB color space of raw milk and UHT milk was measured with a CM-600d spectrophotometer (Konica Minolta, Shanghai, China). Using this technology, L* indicates lightness ranging from 0 to $100, a^{*}$ indicates a range from green to red $(-60$ to +60$)$, and $\mathrm{b}^{*}$ indicates a range from blue to yellow $(-60$ to +60$)$. The $\mathrm{pH}$ was determined using an IoLine electrode (SI
Analytics, Mainz, Germany). The freezing point of the raw milk samples was estimated using MilkoScan FT2 (Foss, Hillerød, Denmark) and SCC using Fossomatic FC (Foss).

Plasmin and plasminogen derived activity was determined according to the method by Korycka-Dahl et al. (1983), with modifications described by de Vries et al. (2016). Total activity was obtained by activation of plasminogen into plasmin by addition of urokinase and plasminogen derived activity was calculated as the difference between the total activity and plasmin activity. Activities were expressed as $\mathrm{U} / \mathrm{mL}$, with 1 unit defined as the amount of enzyme that produces a $\Delta \mathrm{A}_{405}{ }^{1 \mathrm{~cm}}$ of 0.001 in $1 \mathrm{~min}$ at $37^{\circ} \mathrm{C}$ due to $p$-nitroanilide released from the chromogenic substrate.

Total proteolysis was measured on basis of the reaction of primary amino groups of trichloroacetic acid-soluble peptides and free AA with fluorescamine (Wiking et al., 2002). Equal volumes of milk and $24 \%$ trichloroacetic acid were mixed, held on ice for $30 \mathrm{~min}$, and centrifuged at $16,000 \times g$ for 20 min at $4^{\circ} \mathrm{C}(\mathrm{Hi}-$ mac CT15RE, Hitachi Koki Co., Ltd., Tokyo, Japan). The supernatant was mixed with sodium tetraborate and fluorescamine, and the fluorescence (excitation wavelength $390 \mathrm{~nm}$, emission wavelength $480 \mathrm{~nm}$ ) was measured after $18 \mathrm{~min}$ in a luminescence spectrometer (LS 55, Perkin Elmer).

Ethanol stability was defined as the highest ethanol concentration added to the sample without causing visual coagulation of the milk when equal volumes of milk and ethanol, at ethanol concentrations ranging between 40 and $100 \%$ in $2 \%$ increments, were mixed and incubated for 30 min. Heat coagulation time was defined as the time needed for visual coagulation of 0.5 $\mathrm{mL}$ of milk in a sealed test tube while being rocked at $130^{\circ} \mathrm{C}$ (Davies and White, 1966) using the dedicated equipment from Hettich Benelux (Geldermalsen, the Netherlands).

Principal component analysis (PCA) was used to identify months showing similarities with respect to the total variation using SIMCA 13.0 software (Umetrics, Umeå, Sweden). Minitab 17 software (Minitab Ltd., State College, PA) was used to calculate Pearson correlation coefficients for selected quality traits. Samples of raw milk collected in June and July were compared with milk collected during the rest of the year to evaluate differences in milk quality traits between outdoor and indoor periods using Minitab 17 software. The $P$-values were calculated by one-way ANOVA (2-sided 95\% CI). The same comparison was done for the corresponding UHT milk samples.

To study the variation in Swedish raw milk for UHT processing, PCA for raw milk and its corresponding 
Table 1. Descriptive data for the quality traits investigated in raw milk samples collected on a monthly basis during 1 yr with the exception of August $(\mathrm{n}=11)^{1}$

\begin{tabular}{|c|c|c|c|c|c|c|}
\hline \multirow[b]{2}{*}{ Item } & \multicolumn{3}{|c|}{ Outdoor period } & \multicolumn{3}{|c|}{ Indoor period } \\
\hline & Mean & Min & $\operatorname{Max}$ & Mean & Min & Max \\
\hline \multicolumn{7}{|l|}{$\overline{\text { Composition }}$} \\
\hline TS, \% & 13.04 & 12.99 & 13.08 & 13.10 & 12.95 & 13.28 \\
\hline Lactose, \% & 4.73 & 4.73 & 4.73 & 4.71 & 4.64 & 4.74 \\
\hline Fat, $\%$ & 4.14 & 4.11 & 4.16 & 4.19 & 4.13 & 4.28 \\
\hline Protein, $\%$ & 3.44 & 3.43 & 3.45 & 3.46 & 3.41 & 3.53 \\
\hline$\alpha_{\mathrm{S}^{-}} \mathrm{CN}, \%^{2}$ & 28.72 & 27.94 & 29.50 & 28.92 & 27.60 & 30.59 \\
\hline$\alpha_{\mathrm{S} 2}-\mathrm{CN}, \%^{2}$ & 8.26 & 7.89 & 8.64 & 7.94 & 7.06 & 8.48 \\
\hline$\beta-\mathrm{CN}, \%^{2}$ & 41.78 & 40.22 & 43.33 & 39.92 & 36.36 & 43.23 \\
\hline$\kappa-\mathrm{CN}, \%^{2}$ & 3.11 & 1.59 & 4.63 & 4.21 & 1.62 & 6.11 \\
\hline Unknown proteins, $\%^{2}$ & 5.15 & 3.62 & 6.67 & 5.77 & 4.07 & 7.27 \\
\hline Calcium, $\mathrm{mg} / \mathrm{g}$ & 1.19 & 1.12 & 1.26 & 1.22 & 1.12 & 1.31 \\
\hline Potassium, mg/g & 1.31 & 1.14 & 1.47 & 1.41 & 1.27 & 1.55 \\
\hline Total bacteria, cfu/mL & 23,000 & 8,000 & 38,000 & 29,000 & 2,000 & 132,000 \\
\hline Psychrotrophic bacteria, cfu/mL & 8,500 & 5,800 & 11,200 & 216 & 0 & 756 \\
\hline \multicolumn{7}{|l|}{ Enzymatic activity } \\
\hline Total proteolysis, leucine equivalents in $\mathrm{m} M$ & 39.40 & 39.37 & 39.43 & 40.58 & 34.90 & 46.51 \\
\hline Plasmin activity, $\mathrm{U} / \mathrm{mL}$ & 3.09 & 3.00 & 3.17 & 3.35 & 2.22 & 4.22 \\
\hline Plasminogen-derived activity, $\mathrm{U} / \mathrm{mL}$ & 86.69 & 85.67 & 87.71 & 93.08 & 80.86 & 100.22 \\
\hline \multicolumn{7}{|l|}{ CIELAB color space ${ }^{3}$} \\
\hline $\mathrm{L}^{*}$ & 77.19 & 77.08 & 77.30 & 77.88 & 77.35 & 78.69 \\
\hline$a^{*}$ & -0.90 & -1.01 & -0.79 & -0.90 & -1.67 & -0.65 \\
\hline $\mathrm{b}^{*}$ & 6.59 & 6.21 & 6.96 & 7.03 & 6.17 & 7.86 \\
\hline \multicolumn{7}{|l|}{ Other } \\
\hline Ethanol stability, \% & 79 & 78 & 80 & 81 & 70 & 86 \\
\hline Heat coagulation time, min & 13 & 13 & 13 & 19 & 13 & 25 \\
\hline $\mathrm{pH}$ & 6.74 & 6.73 & 6.74 & 6.72 & 6.69 & 6.77 \\
\hline
\end{tabular}

${ }^{1}$ Results are presented as average (mean), lowest $(\min )$, and highest (max) values observed.

${ }^{2} \%$ : Individual proteins expressed as \% of total protein content.

${ }^{3} \mathrm{~L}^{*}$ indicates lightness ranging from 0 to 100 , $\mathrm{a}^{*}$ indicates a range from green to red $(-60$ to +60$)$, and $\mathrm{b}^{*}$ indicates a range from blue to yellow $(-60$ to +60$)$.

UHT milk was carried out based on data summarized in Tables 1 and 2 , respectively. In contrast to our expectations, the PCA for raw milk did not support the hypothesis of seasonal variation. The score plot (Figure 1a) shows a small variation between months, but no clustering of months according to season. The major quality traits contributing to the small differences between months included $\beta$-CN, $\kappa-\mathrm{CN}$, psychrotrophic bacteria, freezing point, urea, and calcium, as illustrated in the loading plot (Figure 1b). Correlations coefficients for some of the investigated quality traits were calculated. In raw milk, strong positive correlations were found for protein, fat, and TS (Table 3), quality traits important for the second principal component. Our results in part agree with the observations by Chen et al. (2014), who found a positive correlation for fat and TS in raw milk but a negative correlation for protein and fat. In contrast to expectations, our data showed no correlation between calcium content and total protein or total casein. A correlation between minerals and casein was also absent in the study by Chen et al. (2014), investigating effects of season on milk composition. In our study, calcium, potassium, and magnesium correlated positively, whereas sodium was not correlated with any of the other traits and had minor influence on the PCA.

The PCA for the UHT milk showed a weak tendency for December, January, and February, as well as July to separate from the other months (Figure 2a), with calcium, magnesium, lactose, and color $\left(\mathrm{L}^{*} \mathrm{a} * \mathrm{~b}^{*}\right)$ being the quality traits mostly contributing to differences between months (Figure 2b). In UHT milk, heat co- 
Table 2. Descriptive data for the quality traits investigated in UHT-processed milk samples collected on a monthly basis during 1 yr with the exception of August $(\mathrm{n}=11)^{1}$

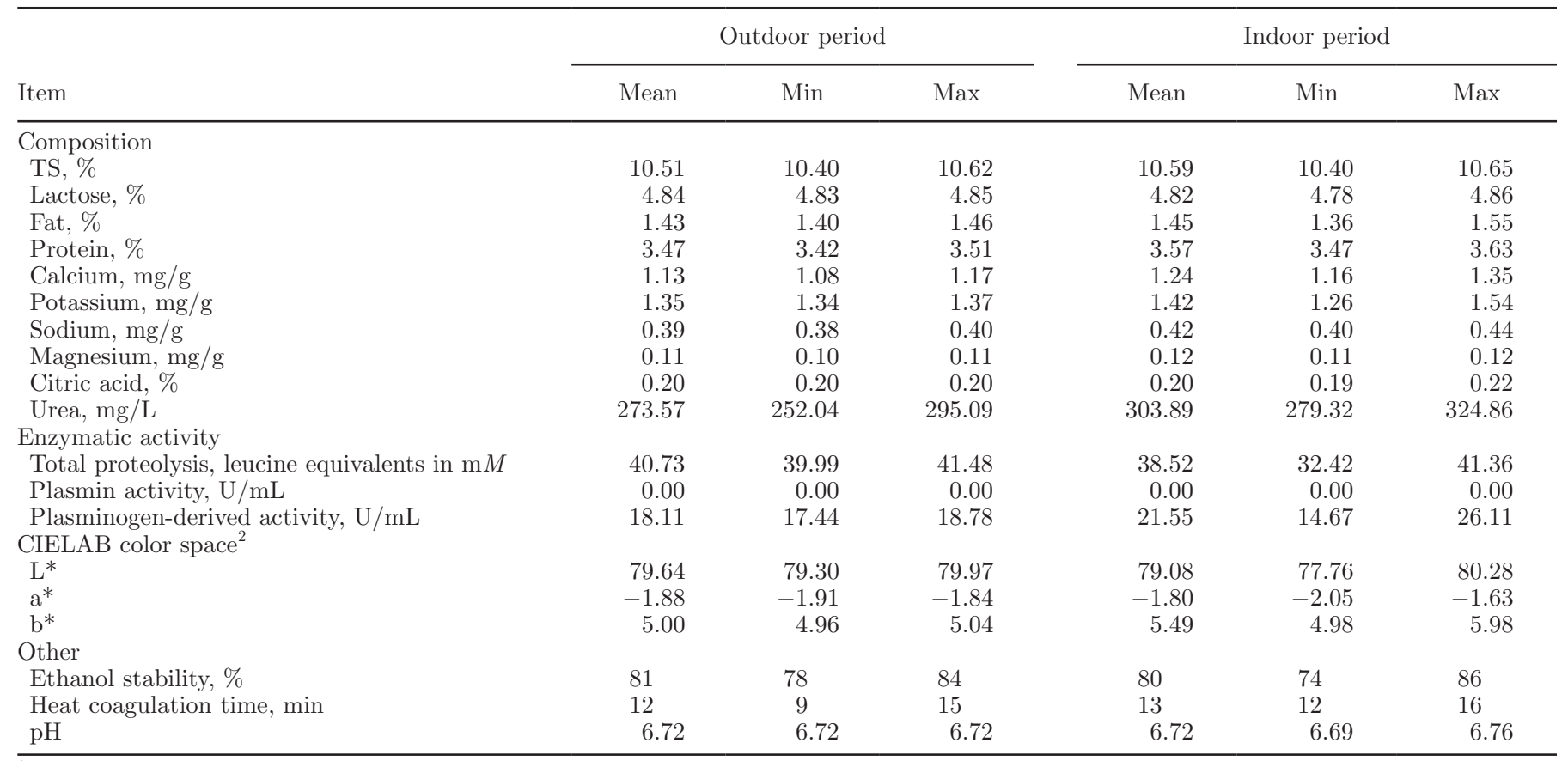

${ }^{1}$ Results are presented as average (mean), lowest (min), and highest (max) values observed.

${ }^{2} \mathrm{~L}^{*}$ indicates lightness ranging from 0 to $100, \mathrm{a}^{*}$ indicates a range from green to red $(-60$ to +60$)$, and $\mathrm{b}^{*}$ indicates a range from blue to yellow $(-60$ to +60$)$.

agulation time and fat showed a positive correlation (Table 4). Lower heat stability has been related to homogenization, but variation in fat content has not previously been shown to affect the heat stability (Huppertz, 2016). Lightness, $\mathrm{L}^{*}$, was negatively correlated with $a^{*}$ and $b^{*}$, whereas $a^{*}$ and $b^{*}$ were positively correlated, and fat content was positively correlated with $a^{*}$ and $b^{*}$. This can be interpreted that differences in color are related to differences in fat content. Milk with more fat will be perceived as more red and yellow (i.e., higher $a^{*}$ and $b^{*}$ values), and consequently lightness will be lower. In UHT milk there were strong positive correlations for the minerals, all to be found clustered in the upper right corner of the PCA (Figure 2b).

The overall average, minimum, and maximum values of the quality traits investigated in raw milk are presented in Table 1. Differences between raw milk samples collected during the outdoor grazing period (June and July) were found for sodium $(P=0.078)$, urea $(P=$ $0.070)$, psychrotrophic bacteria $(P=0.000)$, and $\mathrm{L}^{*}(P$ $=0.042$ ). For UHT milk, differences between outdoor period and the rest of the year were found for protein $(P=0.024)$, calcium $(P=0.043)$, sodium $(P=0.048)$, magnesium $(P=0.043)$, urea $(P=0.073)$, and $\mathrm{b}^{*}(P$ $=0.037)$. In the raw milk, psychrotrophic bacteria and urea, and in the UHT milk, calcium, magnesium, and $b^{*}$ were of importance, both in PCA and ANOVA.
The levels of different components in milk observed in our study were generally in agreement with observations in previous studies on seasonal variation in raw milk; however, using PCA, our study shows only small variation between samples and gives no support for an existing seasonality in the composition and properties of raw milk. One must therefore be careful in the interpretation of the results in Tables 1 and 2 not to make far-reaching conclusions but consider whether the observed differences have any biological relevance.

Investigating the seasonal variation in composition and properties of raw milk from a commercial herd, Chen et al. (2014) observed that total protein as well as casein was higher in spring than during summer and autumn. Lindmark-Månsson (2012) and Heck et al. (2009), investigating the composition of Swedish and Dutch raw milk, respectively, reported the total protein content to be highest during January and December. We observed the highest protein content in November and December $(>3.5 \%)$; the rest of the year the protein content varied around $3.45 \%$. The variation in protein content in raw milk can be derived to diet and stage of lactation, which also explain the large variation in previously reported studies. Because the proportion of protein in the UHT milk will be affected by the fat content, the variation in fat standardization (1.36 to $1.55 \%$ ), will indirectly also affect the protein content 
of the UHT milk. It is, however, difficult to explain the lower protein content in UHT milk during summer months, given that no clear effect was observed of season on protein content in the raw milk.

In contrast to Heck et al. (2009), who reported the lowest urea content in December and highest in August, we found the lowest urea content during the summer months. The average value in our study $(314 \mathrm{mg} / \mathrm{kg})$ was higher than the average value in Swedish raw milk $(280 \mathrm{mg} / \mathrm{kg})$ reported by Lindmark-Månsson (2012). Milk urea has been used as an indicator of the amount of protein in the diet, and in general, the more protein

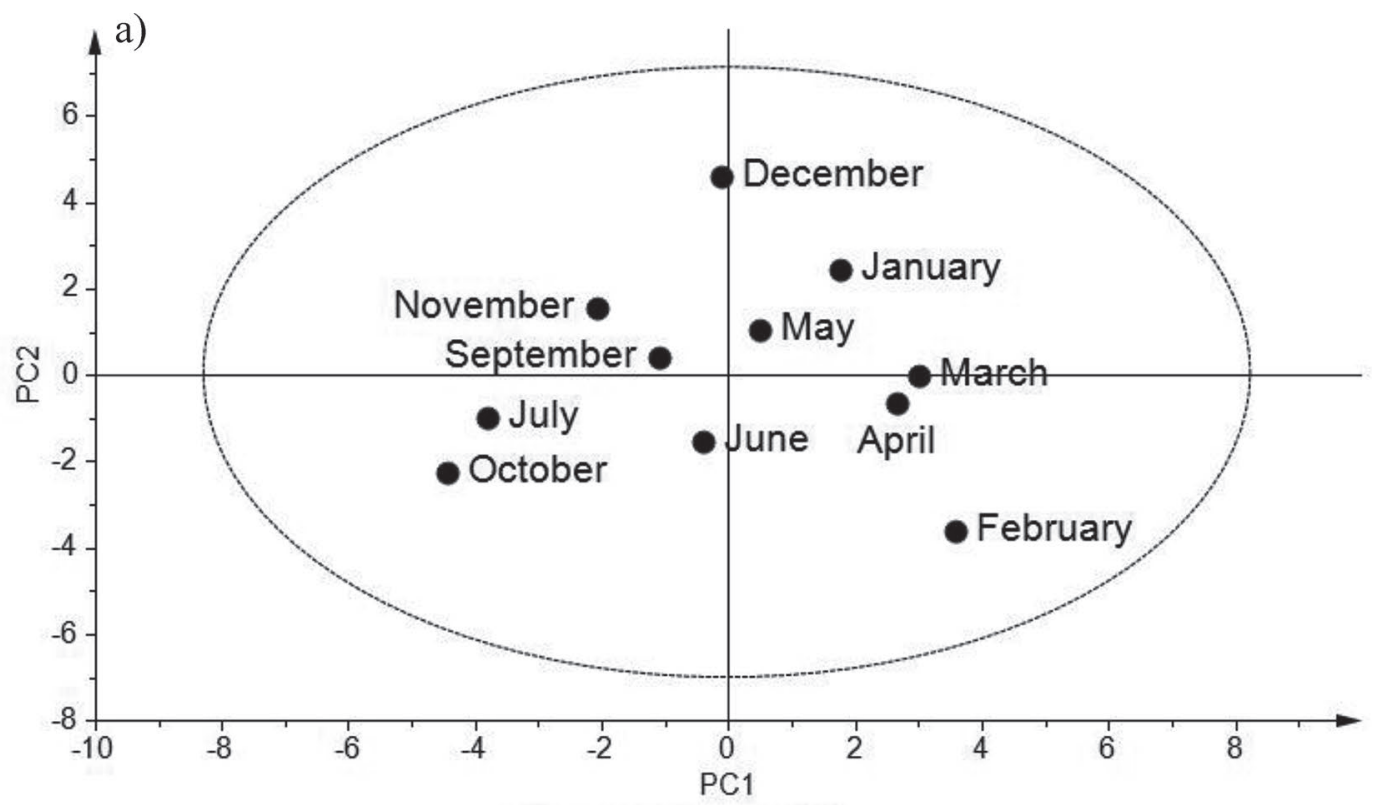

Ellipse: Hotelling's T2 (95\%)

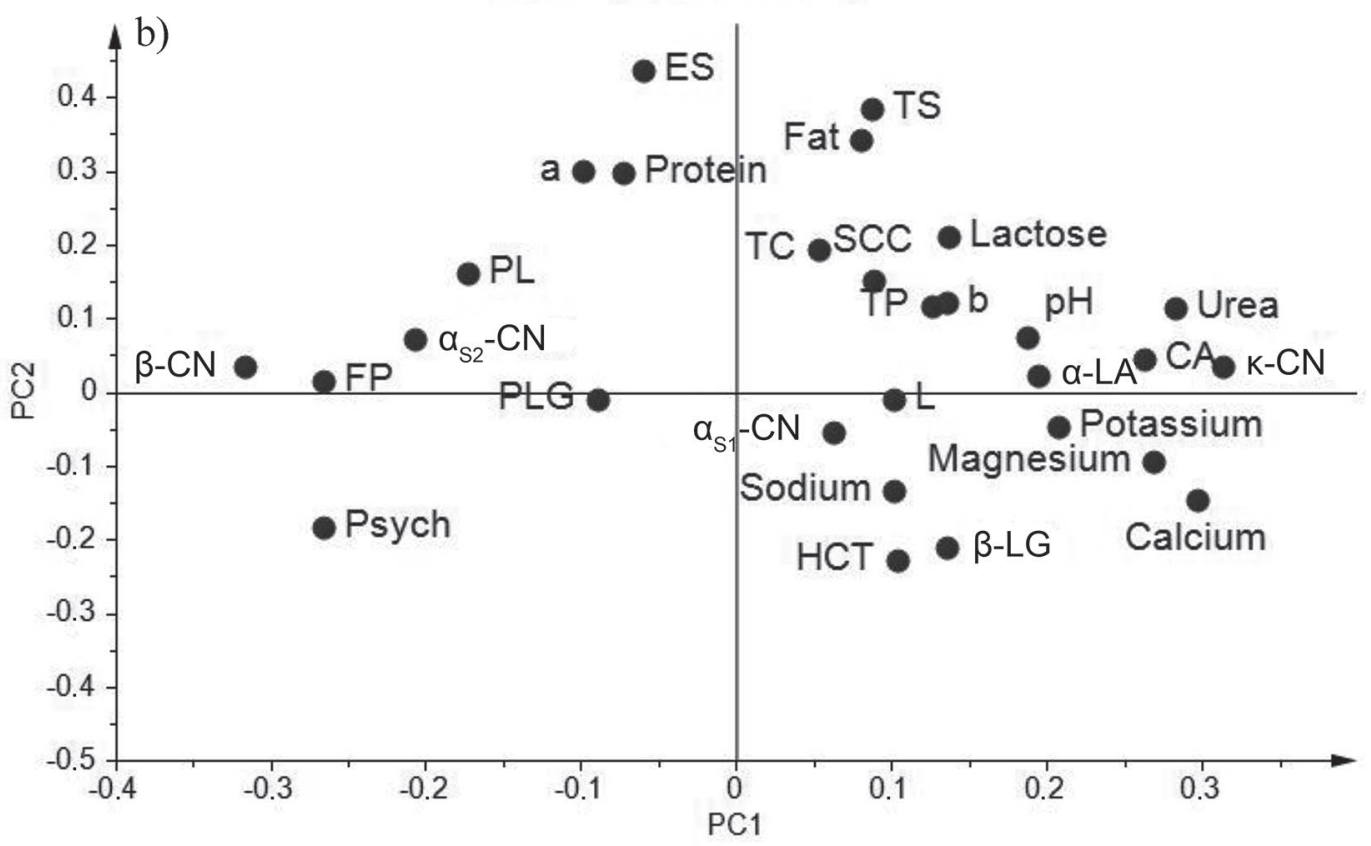

Figure 1. Principal component (PC) analysis of quality traits, (a) score plot and (b) loading plot, for raw milk collected on a monthly basis during $1 \mathrm{yr}$, with the exception of August. Of the total variation, the first and second principal component explained 25 and $17 \%$, respectively. Altogether, the 5 first principal components explained $79 \%$ of the variation in the data set. $\mathrm{CA}=$ citric acid; $\mathrm{ES}=$ ethanol stability; $\mathrm{FP}=$ freezing point; $\mathrm{HCT}=$ heat coagulation time; PL = plasmin activity; PLG = plasminogen-derived activity; Psych = psychrotrophic bacteria; $\mathrm{TC}=$ total bacterial count; $\mathrm{TP}=$ total proteolysis; $\mathrm{L}=\mathrm{L}^{*}$ (lightness); $\mathrm{a}=\mathrm{a}^{*}$ (redness); $\mathrm{b}=\mathrm{b}^{*}$ (yellowness). 
in the diet, the higher the milk urea will be. A high milk urea content in milk from cows grazing quality pasture is therefore common because cows will be consuming excess protein. One reason for the lower urea content during summer months in our study could be the cold weather conditions during the summer of 2015 (SMHI 2016), with low protein content in the pasture and difficulties in providing sufficient high quality forage, likely giving rise to a reduction in protein intake.

In our study the highest levels of calcium in raw milk were observed during January to April and in June (data not shown). In UHT milk calcium levels were highest during November to February and reached a minimum in July. Only small variation, no seasonality, was observed for magnesium content in raw milk. In UHT milk, magnesium was lowest during March to July. Lindmark-Månsson (2012) reported lower calcium and magnesium content in raw milk during summer, levels agreeing with those found in our study, whereas Chen et al. (2014) did not find any seasonal variation in these 2 minerals. Average levels of sodium $(0.40 \mathrm{mg} / \mathrm{g})$ agreed with those reported by Lindmark-Månsson (2012), who observed highest levels of sodium during summer. In our study, the highest sodium content in the raw milk was observed during March, June, and July. In contrast, in UHT milk the lowest levels of sodium were observed during March, April, June, and July. Despite statistically higher sodium content during the outdoor period, no clear, seasonal trend for sodium was observed either in the raw milk or in the corresponding UHT milk. Minerals in pasture vary with regions and soil characteristics, also affecting levels in milk. The variation in mineral content in raw milk was therefore likely to originate from variation in the feed.

The raw milk generally contained low numbers of total bacteria and few or very few psychrotrophic bacteria. The highest total bacteria count was observed in January $(132,000 \mathrm{cfu} / \mathrm{mL})$, whereas psychrotrophic bacteria reached a maximum of $11,200 \mathrm{cfu} / \mathrm{mL}$ in July. The fact that cows were outdoors and most likely subject to contamination by bacteria from the environment

Table 3. Pearson correlation coefficients for selected quality traits in raw milk

\begin{tabular}{lc}
\hline Quality trait & Correlation coefficient \\
\hline Protein/fat & $0.808^{* *}$ \\
Protein/TS & $0.737^{* *}$ \\
Fat/TS & $0.884^{* * *}$ \\
Calcium/potassium & $0.772^{* *}$ \\
Calcium/magnesium & $0.954^{* * *}$ \\
Potassium/magnesium & $0.843^{* * *}$ \\
\hline
\end{tabular}

${ }^{* *} P \leq 0.01 ;{ }^{* * *} P \leq 0.001$. (soil, pasture, water) are likely causes for the peak in psychrotrophic bacteria during the summer months. O'Connell et al. (2016), studying the effect of storage temperature and duration on microbial quality of bulk tank milk, observed increasing counts of psychrotrophic bacteria but not total bacteria counts when the storage temperature increased from 2 to $4^{\circ} \mathrm{C}$. Elevated ambient temperatures giving rise to somewhat higher storage temperatures during summer months could thus also be reasons behind a higher number of psychrotrophic bacteria during the outdoor period. Bacterial numbers were not evaluated in the UHT milk because the process will kill all vegetative bacteria. However, bacteria can still, by residual enzymatic activity, alter the properties of the milk before processing, leading to a shorter shelf life of the final product (Stoeckel et al., 2016).

In a New Zealand study, Nicholas et al. (2002) investigated the effect of stage of lactation and season on plasmin and plasminogen-derived activity. They found no effects of stage of lactation or season on plasmin activity; however, both plasminogen-derived and total plasmin/plasminogen-derived activities were affected. Stage of lactation had a larger effect than season and highest activities were observed at late lactation and in spring. In fresh UHT milk, Garbowska et al. (2010) observed higher proteolytic activity of plasmin, total plasmin/plasminogen activities, and proteolytic changes measured by the concentration of free amino groups, in UHT milk produced from milk during winter. In our study, however, we could not observe any seasonal effects on proteolytic activities, probably due to nonseasonal calving patterns and the very low numbers of psychrotrophic bacteria, limiting the risk for microbial protease activity.

The color of milk, which can be described by the CIELAB color space, primarily depends on the milk fat globule size (Doan, 1924). The color of milk has been shown to vary with stage of lactation, infection (mastitis), breed, and season (Doan, 1924; McDermott et al., 2016) with numerous and smaller milk fat globules (MFG) giving rise to higher reflectance, resulting in a lighter milk. Size of MFG has been reported to be influenced by factors such as diet (Couvreur et al., 2007) and stage of lactation (Mesilati-Stahy and Argov-Argaman, 2014; Altenhofer et al., 2015). In our study, the lower values for lightness in raw milk samples during outdoor season (lower $\mathrm{L}^{*}$-value), were possibly explained by fewer or larger MFG during summer months. Due to homogenization and the resulting increase in number of MFG, L*-values for the UHT milk were higher (i.e., the UHT milk appeared lighter than the raw milk). Moreover, the UHT milk was significantly less yellow during summer months. Despite standardization of the 


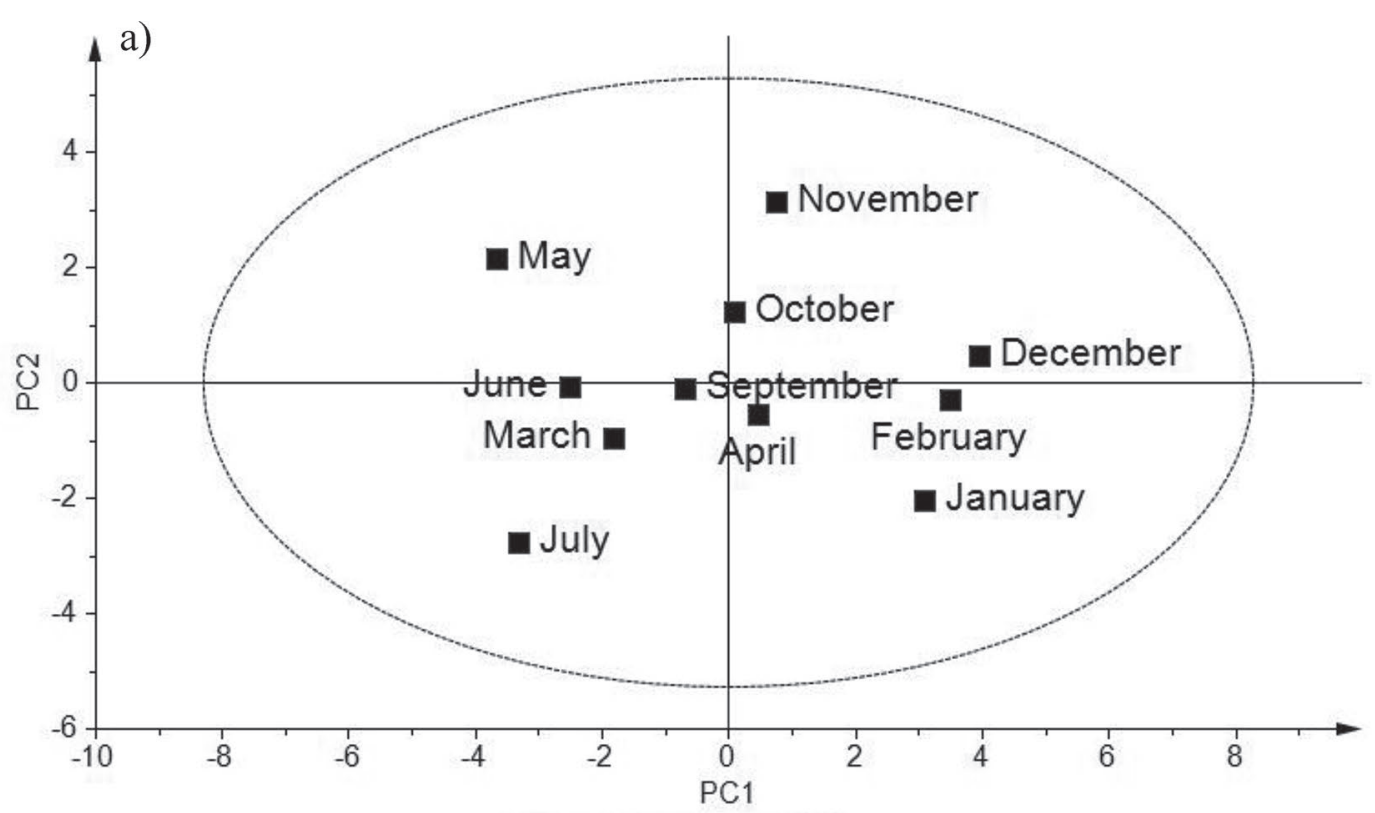

Ellipse: Hotelling's T2 (95\%)

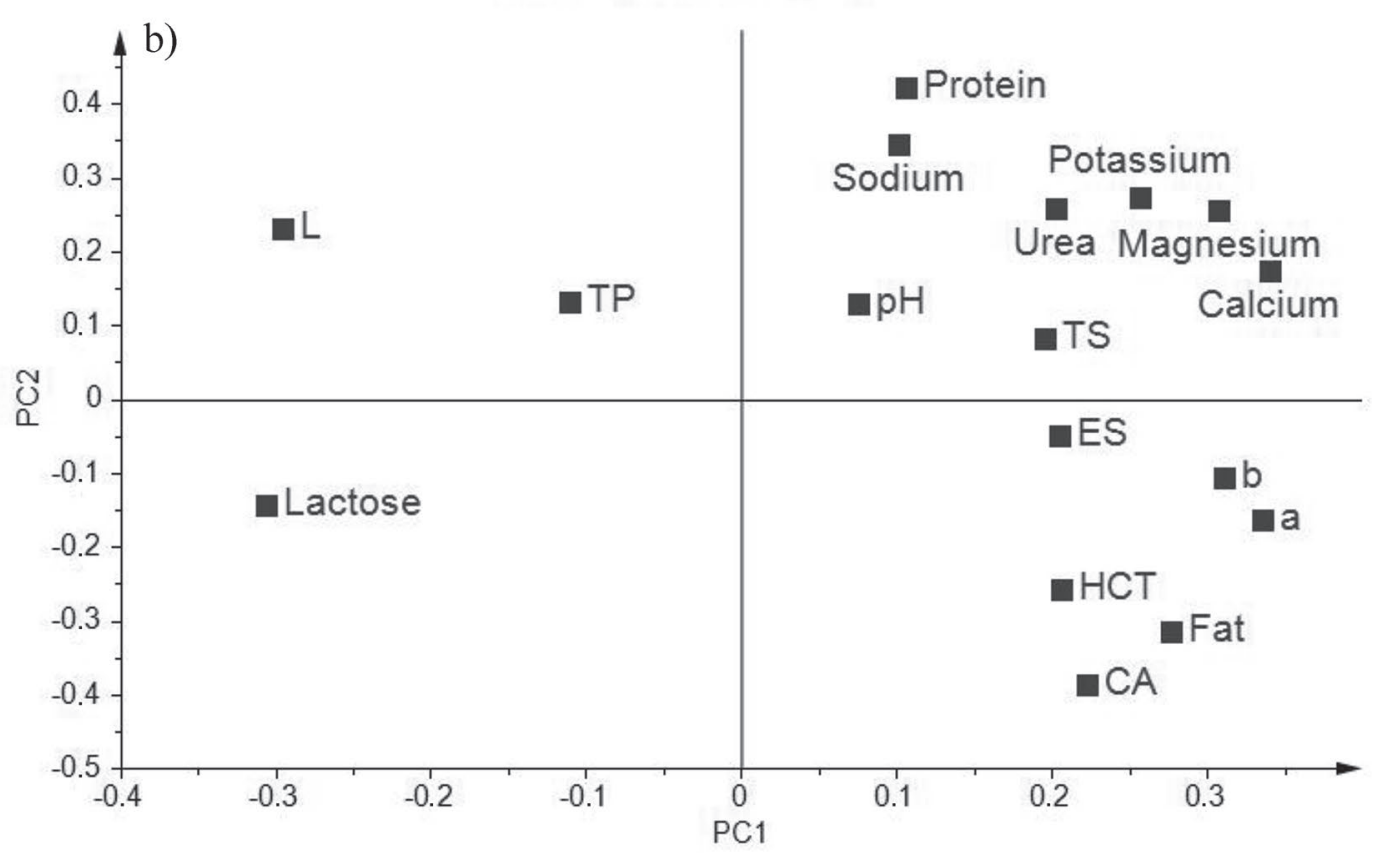

Figure 2. Principal component (PC) analysis of quality traits, (a) score plot and (b) loading plot, for UHT milk collected on a monthly basis during 1 yr, with the exception of August. Of the total variation, the first and second principal component explained 43 and $17 \%$, respectively. Altogether, the 5 first principal components explained $90 \%$ of the variation in the data set. CA $=$ citric acid; ES $=$ ethanol stability; HCT $=$ heat coagulation time; $\mathrm{TP}=$ total proteolysis; $\mathrm{L}=\mathrm{L}^{*}$ (lightness); $\mathrm{a}=\mathrm{a}^{*}$ (redness); $\mathrm{b}=\mathrm{b}^{*}$ (yellowness).

UHT milk, its fat content varied over the year, showing the lowest values from May to October (data not shown). With a lower fat content, the milk will appear less yellow and more blue, explaining this observation.

In conclusion, this study using PCA showed small differences between months but no seasonality in the composition and properties of Swedish raw milk and its corresponding UHT milk. Using ANOVA, we observed differences for some quality traits between milk produced during the outdoor period and milk from the rest of the year. The quality traits contributing to the variation between months were only to some extent the 
Table 4. Pearson correlation coefficients for selected quality traits in UHT milk

\begin{tabular}{lc}
\hline Quality trait & Correlation coefficient \\
\hline Heat coagulation time/fat & $0.769^{* *}$ \\
$\mathrm{~L}^{*} / \mathrm{a}^{*}$ & $-0.886^{* * *}$ \\
$\mathrm{~L}^{*} / \mathrm{b}^{*}$ & $-0.831^{* *}$ \\
$\mathrm{a}^{*} / \mathrm{b}^{*}$ & $0.765^{* *}$ \\
$\mathrm{a}^{*} / \mathrm{fat}$ & $0.775^{* *}$ \\
$\mathrm{~b}^{*} / \mathrm{fat}$ & $0.633^{* *}$ \\
Calcium/potassium & $0.795^{* *}$ \\
Calcium/magnesium & $0.947^{* * *}$ \\
Sodium/magnesium & $0.632^{*}$ \\
Potassium/magnesium & $0.848^{* * *}$ \\
\hline
\end{tabular}

${ }^{1} \mathrm{~L}^{*}$ indicates lightness ranging from 0 to $100, \mathrm{a}^{*}$ indicates a range from green to red $(-60$ to +60$)$, and $\mathrm{b}^{*}$ indicates a range from blue to yellow $(-60$ to +60$)$.

${ }^{*} P \leq 0.05 ;{ }^{* *} P \leq 0.01 ;{ }^{* * *} P \leq 0.001$.

same in raw milk and UHT milk. Our study suggests that with modern and well-managed herds, the variation in raw milk composition is very small throughout the year. Consequently, the effect of seasonality on UHT milk stability is also expected to be small.

\section{ACKNOWLEDGMENTS}

The Faculty of Natural Resources and Agricultural Sciences at SLU is acknowledged for financial contribution. We thank Börje Ericson and Jorge Andre, Department of Animal Nutrition and Management, and our master's students Emma Thorén and Eva Edlund Tjernberg, for their analytical work. Lotte Bach Larsen (Aarhus University, Aarhus, Denmark) is acknowledged providing a detailed protocol for analysis of primary amino groups using the fluorescamine method.

\section{REFERENCES}

Altenhofer, C., W. Holzmüller, F. Wolfertstetter, D. Wolfschoon Ribeiro, U. Kulozik, M. W. Pfaffl, and E. Viturro. 2015. Temporal variation of milk fat globule diameter, fat and cholesterol content and milk epithelial cell gene expression in dairy cows. Int. J. Dairy Technol. 68:519-526. https://doi.org/10.1111/1471-0307.12220.

Andersson, R., and B. Hedlund. 1983. HPLC analysis of organic acids in lactic acid fermented vegetables. Z. Lebensm. Unters. Forsch. 176:440-443. https://doi.org/10.1046/j.1570-7458.1998.00322.x.

Auldist, M. J., B. J. Walsh, and N. A. Thomson. 1998. Seasonal and lactational influences on bovine milk composition in New Zealand. J. Dairy Res. 65:401-411. https://doi.org/10.1017/ S0022029998002970.

Chen, B., M. J. Lewis, and A. S. Grandison. 2014. Effect of seasonal variation on the composition and properties of raw milk destined for processing in the UK. Food Chem. 158:216-223. https://doi. org/10.1016/j.foodchem.2014.02.118.

Couvreur, S., C. Hurtaud, P. G. Marnet, P. Faverdin, and J. L. Peyraud. 2007. Composition of milk fat from cows selected for milk fat globule size and offered either fresh pasture or a corn silage-based diet. J. Dairy Sci. 90:392-403. https://doi.org/10.3168/jds.S00220302(07)72640-1.
Davies, D. T., and J. C. D. White. 1966. The stability of milk protein to heat. I. Subjective measurements of heat stability of milk. J. Dairy Res. 33:67-81.

de Vries, R., M. Brandt, Å. Lundh, K. Holtenius, K. Hettinga, and M. Johansson. 2016. Short communication: Influence of shortening the dry period of Swedish dairy cows on plasmin activity in milk. J. Dairy Sci. 99:9300-9306. https://doi.org/10.3168/jds.2016-11502.

Doan, F. J. 1924. The color of cow's milk and its value. J. Dairy Sci. 7:147-153. https://doi.org/10.3168/jds.S0022-0302(24)94004-5.

Eriksson, T., and B.-O. Rustas. 2014. Effects on milk urea concentration, urine output, and drinking water intake from incremental doses of potassium bicarbonate fed to mid-lactation dairy cows. J. Dairy Sci. 97:4471-4484. https://doi.org/10.3168/jds.2013-7861.

Fox, P. F., and P. L. H. McSweeney. 1998. Dairy Chemistry and Biotechnology. Blackie Academia \& Professional, London, UK.

Garbowska, B., A. Kuncewicz, and H. Panfil-Kuncewicz. 2010. Effect of season on the extent of proteolytic changes in UHT milk stored under various temperature conditions. Milchwissenschaft $65: 270-273$.

Gaucher, I., T. Boubellouta, E. Beaucher, M. Piot, F. Gaucheron, and E. Dufour. 2008. Investigation of the effects of season, milking region, sterilisation process and storage conditions on milk and UHT milk physico-chemical characteristics: A multidimensional statistical approach. Dairy Sci. Technol. 88:291-312. https://doi. org/10.1051/dst:2007022.

Gustavsson, F., A. J. Buitenhuis, M. Johansson, H. P. Bertelsen, M. Glantz, N. A. Poulsen, H. L. Mansson, H. Stalhammar, L. B. Larsen, C. Bendixen, M. Paulsson, and A. Andren. 2014. Effects of breed and casein genetic variants on protein profile in milk from Swedish Red, Danish Holstein, and Danish Jersey cows. J. Dairy Sci. 97:3866-3877. https://doi.org/10.3168/jds.2013-7312.

Heck, J. M. L., H. J. F. van Valenberg, J. Dijkstra, and A. C. M. van Hooijdonk. 2009. Seasonal variation in the Dutch bovine raw milk composition. J. Dairy Sci. 92:4745-4755. https://doi.org/10.3168/ jds.2009-2146.

Huppetz, T. 2016. Heat stability of milk. Pages 179-196 in Advanced Dairy Chemistry. 4th ed. P. L. H. McSweeney and J. A. O'Mahony, ed. Springer New York, New York, NY.

ISO/IDF. 2004. Milk-Estimation of psychrotrophic microorganismsColony-count technique at 21 degrees $\mathrm{C}$ (Rapid method). In Joint Standard 132/ISO 8552. International Dairy Federation, Brussels, Belgium; International Standards Organisation, Geneva, Switzerland.

ISO/IDF. 2007. Milk and milk products-Determination of calcium, sodium, potassium and magnesium contents-Atomic absorption spectrometric method. In Joint Standard 119/ISO 8070. International Dairy Federation, Brussels, Belgium; International Standards Organisation, Geneva, Switzerland.

Jordbruksverket. 2012. An analysis of the Swedish cattle industry. Accessed Oct 14, 2016. http://www.jordbruksverket.se/download/18. 465e4964142dbfe44703101/1387444127813/201203.pdf

Korycka-Dahl, M., B. Ribadeau Dumas, N. Chene, and J. Martal. 1983. Plasmin activity in milk. J. Dairy Sci. 66:704-711.

Lindmark-Månsson, H. 2012. Den svenska mejerimjölkens sammansättning 2009. The Swedish Dairy Association. Report No. 7094.

Lindmark-Månsson, H., R. Fondén, and H.-E. Pettersson. 2003. Composition of Swedish dairy milk. Int. Dairy J. 13:409-425. https:// doi.org/10.1016/S0958-6946(03)00032-3.

McDermott, A., G. Visentin, S. McParland, D. P. Berry, M. A. Fenelon, and M. De Marchi. 2016. Effectiveness of mid-infrared spectroscopy to predict the color of bovine milk and the relationship between milk color and traditional milk quality traits. J. Dairy Sci. 99:3267-3273. https://doi.org/10.3168/jds.2015-10424.

Mesilati-Stahy, R., and N. Argov-Argaman. 2014. The relationship between size and lipid composition of the bovine milk fat globule is modulated by lactation stage. Food Chem. 145:562-570. https:// doi.org/10.1016/j.foodchem.2013.08.077.

Nicholas, G. D., M. J. Auldist, P. C. Molan, K. Stelwagen, and C. G. Prosser. 2002. Effects of stage of lactation and time of year on plasmin-derived proteolytic activity in bovine milk in New 
Zealand. J. Dairy Res. 69:533-540. https://doi.org/10.1017/ S0022029902005745.

Nordic Committee on Food Analysis (NMKL). 1999. Aerobic microorganisms. Determination in foods. Method no. 86, 3rd ed. NMKL Secretariat, Oslo, Norway.

O'Connell, A., P. L. Ruegg, K. Jordan, B. O'Brien, and D. Gleeson. 2016. The effect of storage temperature and duration on the microbial quality of bulk tank milk. J. Dairy Sci. 99:3367-3374. https:// doi.org/10.3168/jds.2015-10495.

SMHI. 2016. Sommaren 2015 - Kall i början men varm på slutet. Accessed Oct. 14, 2016. http://www.smhi.se/klimat/ arssammanstallningar/vader/sommaren-2015-kall-i-borjan-menvarm-pa-slutet-1.93193.

Sola-Larrañaga, C., and I. Navarro-Blasco. 2009. Chemometric analysis of minerals and trace elements in raw cow milk from the com- munity of Navarra, Spain. Food Chem. 112:189-196. https://doi org/10.1016/j.foodchem.2008.05.062.

Stoeckel, M., M. Lidolt, V. Achberger, C. Glück, M. Krewinkel, T. Stressler, M. von Neubeck, M. Wenning, S. Scherer, L. Fischer, and J. Hinrichs. 2016. Growth of Pseudomonas weihenstephanensis, Pseudomonas proteolytica and Pseudomonas sp. in raw milk: Impact of residual heat-stable enzyme activity on stability of UHT milk during shelf-life. Int. Dairy J. 59:20-28. https://doi. org/10.1016/j.idairyj.2016.02.045.

Wiking, L., M. B. Fröst, L. B. Larsen, and J. H. Nielsen. 2002. Effects of storage conditions on lipolysis, proteolysis and sensory attributes in high quality raw milk. Milchwissenschaft 57:190-194.

Williams, R. P. W. 2002. The relationship between the composition of milk and the properties of bulk milk products. Aust. J. Dairy Technol. 57:30-44. 